\title{
The spider genus Creugas Thorell, 1878 in the Afrotropical Region (Araneae: Corinnidae)
}

\section{Пауки рода Creugas Thorell, 1878 (Araneae: Corinnidae) Афротропики}

\author{
Charles R. Haddad \\ Y.P. ХадАаА
}

Department of Zoology \& Entomology, University of the Free State, P.O. Box 339, Bloemfontein 9300, South Africa. E-mail: haddadcr@ufs.ac.za

KEY WORDS: Africa, Aranei, pantropical, Indian Ocean islands

КЛЮЧЕВЫЕ СЛОВА: Африка, Aranei, пантропический, острова Индийского Океана.

ABSTRACT. The spider genus Creugas is represented by a single species in the Afrotropical Region, C. gulosus Thorell, 1878. The species is redescribed, figures of the habitus and copulatory organs are provided, and its distribution in the Afrotropical Region is updated.

How to cite this article: Haddad Ch.R. 2020. The spider genus Creugas Thorell, 1878 in the Afrotropical Region (Araneae: Corinnidae) // Arthropoda Selecta. Vol.29. No.1. P.82-86. doi: 10.15298/arthsel. 29.1.06

РЕЗЮМЕ. Пауки рода Creugas представлены в Афротропике единственным видом C. gulosus Thorell, 1878. Этот вид переописан, приведены иллюстрации внешнего вида, копулятивных органов и карта распространения в регионе.

\section{Introduction}

The dark sac spider genus Creugas Thorell, 1878 comprises nearly twenty species, occurring primarily in South America [WSC, 2019]. A single pantropical species, the type species C. gulosus Thorell, 1878, occurs in tropical South and North America, SouthEast Asia, Australia and the Pacific islands of Hawaii, Marquesas and Samoa [Bonaldo, 2000; Deeleman-Reinhold, 2001; Raven, 2015]. It is also the only species recorded from continental Africa, Reunion and the Seychelles to date [Simon, 1886, 1910; Lessert, 1946; Bonaldo, 2000; Saaristo, 2002, 2010; Jacquot et al., 2016].

The wide global distribution of C. gulosus has inevitably resulted in the description of this species under 18 different names (for complete bibliography and synonyms see Bonaldo [2000] and WSC [2019]), including one species described from Africa, Creugas senegalensis Simon, 1886. In this paper, a redescrip- tion of C. gulosus is given, with comments on its distribution in the Afrotropical Region.

\section{Material and methods}

The spiders included in this study were examined and photographed using a Nikon SMZ800 stereomicroscope with a coupled Nikon D5-L3 camera system. A series of digital photographs were taken of habitus and genitalic structures and stacked using CombineZM imaging software [http:// www.hadleyweb.pwp.blueyonder.co.uk] to increase the depth of field. All measurements are given in millimetres, and leg spination follows the format of Bosselaers \& Jocqué [2000], including the following abbreviations: do - dorsal; $\mathrm{pl}$ prolateral; plv — prolateral ventral; $\mathrm{rl}$ - retrolateral; rlv retrolateral ventral; vt - ventral terminal.

The distribution maps were created using the online software SimpleMappr [Shorthouse, 2010]. Where locality co-ordinates were not available on depository labels, they were searched for using Google Earth [https://www.google. com/earth/], and are presented in square brackets.

The following abbreviations are used in the descriptions: AER - anterior eye row; AL — abdomen length; ALE - anterior lateral eye; AME - anterior median eye; AW - abdomen width; CL — carapace length; CW carapace width; FL — fovea length; MOQ- — median ocular quadrangle, AW - anterior width, L — length, PW posterior width; PER - posterior eye row; PERW - eye row width; PLE - posterior lateral eye; PME - posterior median eye; SL — sternum length; SW - sternum width; $\mathrm{TL}$ - total length;

The material examined in this study is deposited in the following collections (curators in parenthesis): MNHN Muséum National d'Histoire Naturelle, Paris, France (Christine Rollard); MRAC - Royal Museum for Central Africa, Tervuren, Belgium (Rudy Jocqué); MZT — Zoological Museum, University of Turku, Turku, Finland (Seppo Koponen); NCA - National Collection of Arachnida, ARC - Plant Health and Protection, Pretoria, South Africa (Ansie Dippenaar-Schoeman, Petro Marais); USNM - National Museum of Natural History, Smithsonian Institute, Washington D.C., U.S.A. (Jonathan Coddington). 


\section{Taxonomy}

\section{Corinnidae Karsch, 1880}

\author{
Creugas Thorell, 1878
}

Type species: Creugas gulosus Thorell, 1878, from Ambon, Indonesia.

\section{Creugas gulosus Thorell, 1878 Figs $1 \mathrm{~A}-\mathrm{D}, 2 \mathrm{~A}-\mathrm{E}$.}

Creugas gulosus Thorell, 1878: 175 (juv.); Bonaldo, 2000: 98, figs 5-6, 18, 28, 44, 106-107, 261-270 (O'+); Saaristo, 2002: 6,

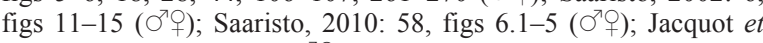
al., 2016: 422, fig. 1a-f ( $\sigma^{7}+$ ).

Creugas senegalensis Simon, 1886: 376 (†).

Corinna senegalensis: Simon, 1898: 196; Simon, 1910: 384 fig. $16\left(O^{7}\right)$; Lessert, 1946: 213, fig. $13\left(O^{7}\right)$.

Only combinations and references relevant to Afrotropical Region included. For full bibliography see WSC [2019].

TYPE MATERIAL. Holotype + of Creugas senegalensis: SENEGAL: Dakar $\left[14^{\circ} 45^{\prime} \mathrm{N}, 17^{\circ} 25^{\prime} \mathrm{W}\right]$, leg. M.E. Blondel, MNHN 4880 - examined.

MATERIAL EXAMINED. BENIN: No specific locality, 2003, leg. S. Tchibozo, $1 \sigma^{7}$ (MRAC 215025); Université d'AbomeyCalavi, $06^{\circ} 27^{\prime} \mathrm{N}, 02^{\circ} 21^{\prime} \mathrm{E}$, 28.XII.2002, leg. S. Tchibozo (on leaves of mango and other fruit trees), $1 \sigma^{7}$ (MRAC 212767). CAMEROON: Galim $\left[07^{\circ} 05^{\prime} \mathrm{N}, 12^{\circ} 28^{\prime} \mathrm{E}\right], 13-20$.VIII.1971, leg. F. Puylaert, $1 \sigma^{7}$ (MRAC 141387). CAPE VERDE ISLANDS: Ile Santo Antao, Ponta do Sol, $17^{\circ} 12^{\prime}$ N, $25^{\circ} 06^{\prime}$ W, 15.XI.1998, leg. W. Tavernier (in bathroom), $1 \mathrm{O}^{2}$ (MRAC 208425). DEMOCRATIC REPUBLIC OF THE CONGO: Bafwasende, $01^{\circ} 00^{\prime} \mathrm{N}, 27^{\circ} 09^{\prime} \mathrm{E}$, leg. R. de Lessert, $1 \sigma^{7}$ (MRAC 212782); Tshopo, Avabuki, $01^{\circ} 19^{\prime} \mathrm{N}$, $27^{\circ} 33^{\prime} \mathrm{E}$, leg. Delhaize, $1 \mathrm{O}^{\top}$ (MRAC 12425). LIBERIA: Monrovia, Montserrado Co., $06^{\circ} 19^{\prime} \mathrm{N}, 10^{\circ} 48^{\prime} \mathrm{W}, 1894$, leg. O.F. Cook Collection, $1 \sigma^{7}$ (USNM). NIGERIA: Benue-Plateau, Jos, $09^{\circ} 55^{\prime} \mathrm{N}$, $08^{\circ} 54^{\prime} \mathrm{E}, \mathrm{X}-\mathrm{XII} .1965$, leg. E. Bot Gwong, $1 \mathrm{O}^{7}$ (MRAC 130619). SEYCHELLES: Aride Island $\left[04^{\circ} 12^{\prime} \mathrm{S}, 55^{\circ} 39^{\prime} \mathrm{E}\right]$, VII-IX.2000, leg. J. Bowler (litter sampling), $1 \sigma^{7}$ (MZT AA 2.120); Cousine Island

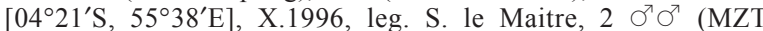
AA0.406); Same locality, 10.XI.1996, leg. O. Bourquin (in house), $1 \sigma^{7}$ (MZT AA 0.387); Same locality, 4.X.2008, leg. R. Gaigher (pitfalls under Pisonia grandis), $1 \mathrm{O}^{7}$ (NCA 2010/254); Same locality, E-end, 24.I.1999, leg. M. Saaristo (among rotten coconut leaves), $10 \mathrm{imm} .1 \mathrm{O}^{7} 2$ 우 (MZT AA 0.442); Same locality, W-end "pedestal", 25.I.1999, leg. M. Saaristo (coconut leaves etc.), 3 imm. 1 (MZT AA 0.443); Same locality, W-end after Pisonia forest, 25.I.1999, leg. M. Saaristo, 1sa O (MZT AA 0.444); Same locality, close to office, 25.I.1999, leg. M. Saaristo (shaking coconut leaves), 1sa (MZT AA 0.445); Mahé Island, Sans Soucis [04 $\left.{ }^{\circ} 39^{\prime} \mathrm{S}, 55^{\circ} 26^{\prime} \mathrm{E}\right]$, II.2002, leg. P. Matyot, $1 \mathrm{O}^{\top} 1$ ㅇ (MZT AA

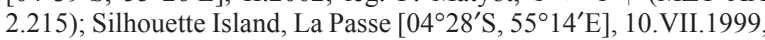
leg. J. Gerlach (in house), $1 \bigcirc^{7}$ (MZT AA 1.303); Vaches Island [04 $41^{\prime}$ S, 55 $\left.26^{\prime} \mathrm{E}\right]$, 15.VIII.1972, leg. P.L.G. Benoit \& J.J. van Mol, 1 q (MRAC 143426). SIERRA LEONE: Freetown $\left[08^{\circ} 28^{\prime} \mathrm{N}\right.$, $\left.13^{\circ} 13^{\prime} \mathrm{W}\right], 1 \mathrm{O}^{\top} 1$ ㅇ (MNHN 10713).

DIAGNOSIS. Creugas gulosus can be recognized from other Afrotropical Corinninae by the somatic characters and shape of copulatory organs. Both sexes have a relative low carapace in lateral profile, while the cephalic regions of Mandaneta Strand, 1932 and Procopius Thorell, 1899 are greatly raised (see Haddad \& Bosselaers, 2010: figs 16, 20). It can be distinguished from Pseudocorinna Simon, 1910 and Crinopseudoa Jocqué \& Bosselaers, 2011 by the absence of carapace warts and the broader cephalic region, which is markedly narrowed in the latter genera [Jocqué, Bosselaers, 2011: figs 3F, 43E]. Females have a distinctly raised transverse median plate in the posterior half of the epigyne, with openings anteriorly and posteriorly (Fig. 1E), forming a continuous channel into which the male palpal conductor presumably fits during copulation. Males can be distinguished from other genera, particularly Pronophaea Simon, 1897 and Austrophaea Lawrence, 1938, by the conductor being clearly separated from the embolus, larger and translucent ( $c f$. Fig. 1G with figs 30 and 32 in Haddad \& Bosselaers, 2010). Males also lack the distinctive modified distal cymbial setae found in the latter two genera.

DESCRIPTION. Female (Sans Soucis, MZT AA 2.215). Measurements: CL 3.25, CW 2.60, AL 4.18, AW 2.63, TL 7.20, FL 0.27, SL 1.70, SW 1.56, AME-AME 0.09, AMEALE 0.06, ALE-ALE 0.51, PME-PME 0.16, PME-PLE 0.17, PLE-PLE 0.75, PERW 0.97, MOQAW 0.43, MOQPW 0.39, MOQL 0.40.

Length of leg segments: I $10.41(2.70,1.22,2.45,2.25$, 1.79); II 9.45 (2.47, 1.15, 2.10, 2.08, 1.65); III 9.12 (2.34, $1.10,1.85,2.35,1.48)$; IV $11.75(3.10,1.25,2.65,3.15$, $1.60)$.

Habitus of female as in Fig. 1A, of holotype of $C$. senegalensis in Fig. 1B. Carapace surface finely granulate, covered in white feathery setae, with scattered long erect black setae along midline, denser behind fovea, longest in eye region; carapace deep orange-brown, with faint black mottling around striae; eye region darker. AER strongly procurved, medians larger than laterals; AME separated by distance equal to $1 / 2$ their diameter; AME separated from ALE by $1 / 3$ AME diameter; clypeus height equal to AME diameter; PER procurved, laterals larger than medians, smaller than anterior eyes; PME separated by distance equal to $1 \frac{1}{3}$ their diameter; PME separated from PLE by distance equal to $1 \frac{1}{2}$ PME diameter; $\mathrm{CW}: \mathrm{PERW}=2.68: 1$. Chelicerae deep red-brown, with scattered long black setae on anterior surface of paturon; three teeth on promargin, median tooth largest, distal and proximal teeth smaller, subequal; retromargin with four evenly spaced teeth, decreasing slightly in size distally; chilum split; endites and labium orange-brown, with scattered straight setae, darker proximally; distal ends of endites cream at dense maxillar hair tuft; serrula distinct; labium slightly broader than long; sternum orange, darker around margins; precoxal triangles present; intercoxal sclerites present between coxae I and II, and II and III, absent between III and IV; pleural bars isolated. Legs orangebrown, with faint black mottling on femora, metatarsi and tarsi slightly darker; femora covered in black feathery setae, patellae to metatarsi with white feathery setae; retrocoxal window present on coxae I. Leg spination: femora: I pl 1 do 2, II pl 1-2 do 2 , III pl 2 do 3 rl 2, IV pl 2 do $2-3 \mathrm{rl} 1$; patellae: without do terminal seta; tibiae: I plv $5-6$ rlv 5 vt 2 , II plv 5 rlv 4 vt 2 , III pl 2 do 1 rl 2 plv 2 rlv 2 vt 2 , IV pl 2 rl 2 plv 2 rlv 2 vt 2 ; metatarsi: I plv 2 rlv 2 , II plv 2 rlv 2 , III pl 3 rl 3 plv 2 rlv 2 vt 1 , IV pl 3 rl 3 plv 2 rlv 2 vt 1 . Palpal spination: femora: pl 1 do 2; patellae: spineless; tibiae: pl 2 plv 1; tarsi: pl 1 plv 1 vt 2 . Abdomen mottled grey dorsally, without markings; dorsal scutum absent; one pair of sigilla present, at abdomen $1 / 3$ length; dorsum covered in light brown feathery setae, with scattered short straight brown setae; venter creamy-grey, without ventral or inframamillary sclerites; venter with light brown and yellowish feathery setae, with scattered brown straight setae.

Epigyne with transverse median ridge, open anteriorly and posteriorly, forming continuous open channel; copulatory ducts positioned posterolaterally (Fig. 1E); spermathecae teardrop-shaped, located laterally, with additional round lobe on mesal margin (Fig. 1F). 

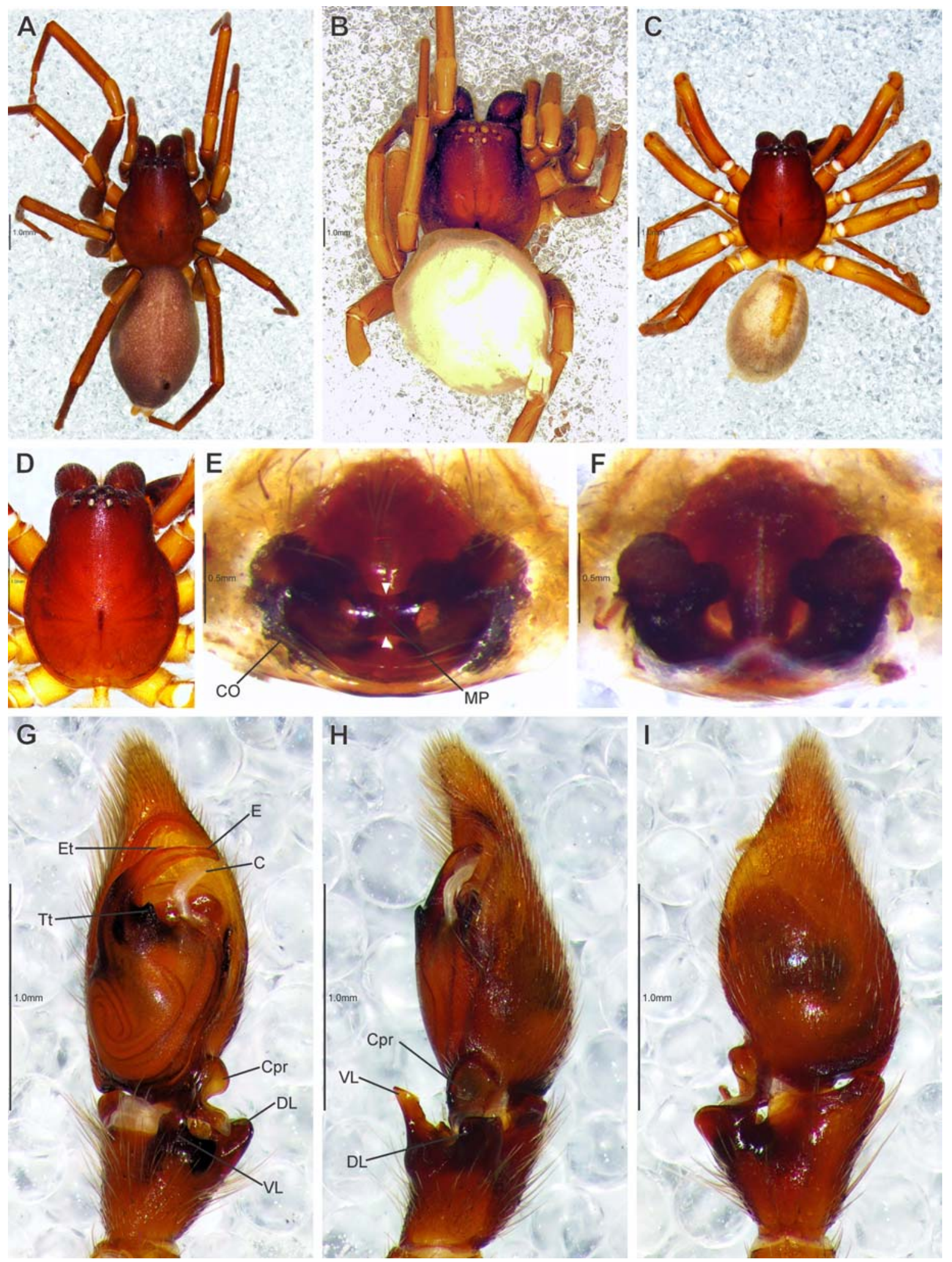

Fig. 1. Habitus and copulatory organs of Creugas gulosus. A - female from Sans Soucis, dorsal habitus; B - female holotype of $C$. senegalensis from Dakar, dorsal habitus; $\mathrm{C}$ - male from Cousine, dorsal habitus; D — same, carapace in dorsal view; E-F — epigyne in ventral $(\mathrm{E})$ and dorsal $(\mathrm{F})$ views, arrowheads indicating anterior and posterior openings of transverse median ridge; G-I - male palp in ventral $(\mathrm{G})$, retrolateral $(\mathrm{H})$ and dorsal $(\mathrm{I})$ views. Abbreviations: $\mathrm{C}$ - conductor; $\mathrm{CO}$ - copulatory opening; $\mathrm{CPr}$ - basal prolateral cymbial process; DL — dorsal lobe of retrolateral tibial apophysis; E — embolus; Et — embolic tooth; MP — median plate; Tt — tegular tooth; VL — ventral lobe of retrolateral tibial apophysis. 


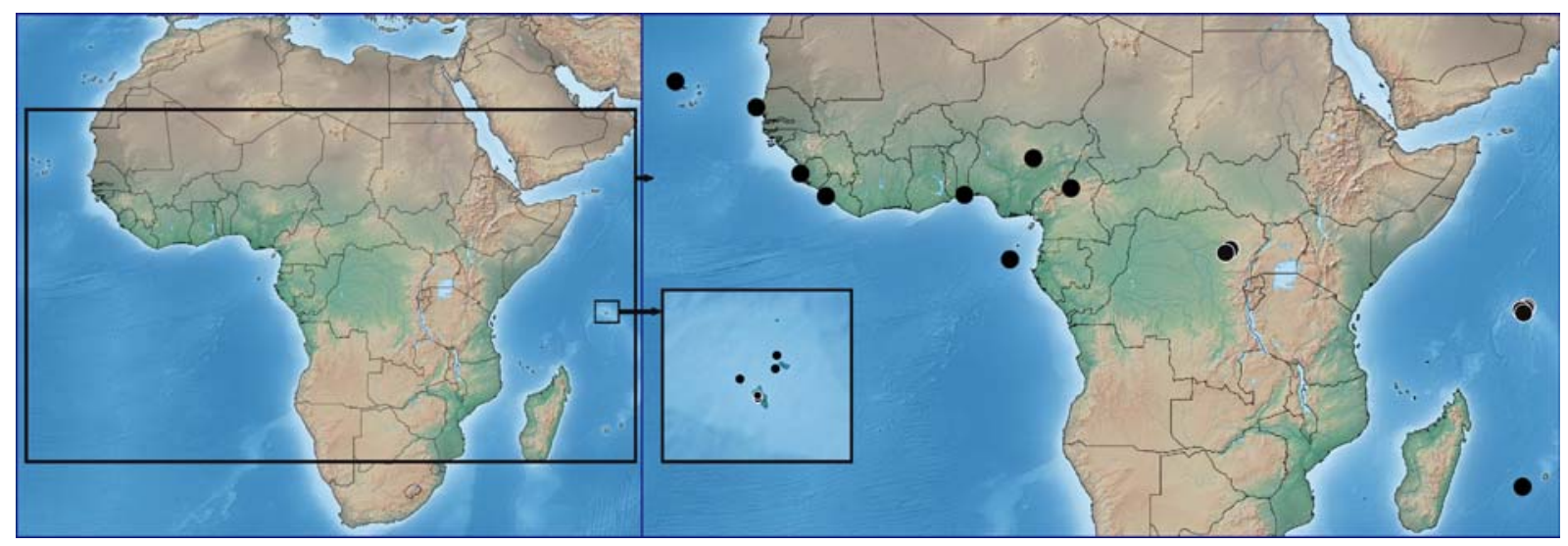

Fig. 2. Map of Africa, enlargements showing the distribution of Creugas gulosus in the Afrotropical Region and the Seychelles archipelago.

Рис. 2. Карта Африки, показывающая распространения Creugas gulosus в Афротропике и на Сейшелах.

Male (Cousine, NCA 2010/254). Measurements: CL 3.22, CW 2.50, AL 3.45, AW 2.25, TL 6.70, FL 0.34, SL 1.61, SW 1.50, AME-AME 0.06, AME-ALE 0.04, ALE-ALE 0.51, PME-PME 0.17, PME-PLE 0.19, PLE-PLE 0.76, PERW 0.97, MOQAW 0.44, MOQPW 0.41, MOQL 0.41.

Length of leg segments: I $10.01(2.66,1.15,2.40,2.10$, 1.70); II $9.04(2.45,1.08,1.96,2.00,1.55)$; III 8.14 (2.18, $0.95,1.65,2.10,1.26)$; IV $10.78(2.86,1.10,2.39,2.97$, $1.46)$.

Habitus of male as in Figs 1C-D. Colouration slightly brighter than female. Morphology similar to female except for the following: AME separated by distance equal to $1 /$ their diameter; AME separated from ALE by $1 / 4$ AME diameter; clypeus height equal to $1 \frac{1 / 4}{4} \mathrm{AME}$ diameter; PME separated by distance equal to $1 \frac{1}{4}$ their diameter; PME separated from PLE by distance equal to $1 \frac{1}{3}$ PME diameter; CW:PERW $=2.58: 1$. Leg spination: femora: I pl 1 do 2 , II pl 1 do 2 , III pl 1 do 3 rl 2, IV pl 1 do 3 rl 1; patellae: without do terminal seta; tibiae: I plv 6 rlv 5 vt 2 , II plv $4-5$ rlv 4 vt 2 , III pl 2 do 1 rl 2 plv 2 rlv 2 vt 2 , IV pl 2 do 1 rl 2 plv 2 rlv 2 vt 2 ; metatarsi: I plv 2 rlv 2 , II plv 2 rlv 2 , III pl 3 rl 3 plv 2 rlv 2 vt 1 , IV pl 3 rl 3 plv 2 rlv 2 vt 1 . Palpal spination: femora: $\mathrm{pl}$ 1 do 2; patellae: spineless; tibiae: pl 2 plv 1; tarsi: pl 1 plv 1 vt 2. Abdomen with narrow orange-yellow dorsal scutum extending to midpoint of dorsum, venter without sclerites.

Palp elongate-oval, tip of cymbium pointed; cymbium with large proximal retrolateral apophysis; palpal tibia with lobate prolateral apophysis, retrolateral apophysis comprising digitiform ventral lobe and broad quadrangular dorsal lobe; tegulum oval, with distal tooth positioned retrolateral of embolus base; embolus originating distally on prolateral side of tegulum, transverse, curving retrolaterally, with small tooth on distal margin; conductor long, curved, translucent, originating medially at distal end of tegulum (Figs $1 \mathrm{G}-\mathrm{I}$ ).

DISTRIBUTION. Widespread in tropical South America [Bonaldo, 2000], presumably introduced into North America, Australia, South-East Asia, various Pacific islands, and Africa [WSC, 2019]. In Africa, previously recorded from
Senegal [Simon, 1886], Sao Tomé [Simon, 1910], D.R. Congo [Lessert, 1946], Nigeria, Cameroon and Sierra Leone [Bonaldo, 2000], Seychelles [Bonaldo, 2000; Saaristo, 2002, 2010] and Reunion [Jacquot et al., 2016]. Widely distributed but rare throughout tropical continental Africa; also occurring on the Indian Ocean islands of Seychelles and Reunion (Fig. 2).

Acknowledgements. The curators of the collections are thanked for their loans of specimens that made this study possible. This work was funded through grants from the National Research Foundation of South Africa (NRF) in the Thuthuka programme (\#69017) and Competitive Funding for Rated Researchers programme (\#95569). Jan Bosselaers and an anonymous referee are thanked for their comments that helped improve the manuscript.

\section{References}

Bonaldo A.B. 2000. Taxonomia da subfamília Corinninae (Araneae, Corinnidae) nas regiões Neotropica e Neárctica // Iheringia, Série Zoologia. Vol.89. P.3-148.

Bosselaers J., Jocqué R. 2000. Studies in Corinnidae: transfer of four genera and description of the female of Lessertina mutica Lawrence 1942 // Tropical Zoology. Vol.13. P.305-325.

Deeleman-Reinhold C.L. 2001. Forest spiders of South East Asia: with a revision of the sac and ground spiders (Araneae: Clubionidae, Corinnidae, Liocranidae, Gnaphosidae, Prodidomidae and Trochanterriidae [sic]). Leiden: Brill. $591 \mathrm{p}$.

Haddad C.R., Bosselaers J. 2010. A revision of the genus Medmas$s a$ Simon, 1887 (Araneae: Corinnidae) in the Afrotropical Region // Zootaxa. Vol.2361. P.1-12.

Jacquot M., Derepas B., Deguine J.-P. 2016. Seven newly recorded species and families of spiders from Reunion Island (Malagasy region) (Araneae, Araneomorphae) // Bulletin de la Société Entomologique de France. Vol.121. P.421-430.

Jocqué R., Bosselaers J. 2011. Revision of Pseudocorinna Simon and a new related genus (Araneae: Corinnidae): two more examples of spider templates with a large range of complexity

Рис. 1. Габитус и копулятивные органы Creugas gulosus. A - самка из Sans Soucis, сверху; В - голотип самка из Дакара, сверху; C - самец из о-ва Cousine, сверху; D - карапакс самца, сверху; E-F — эпигина, вентрально и дорзально (стрелками показаны передний и задний край медиального гребня; G-I - пальпа самца, снизу, ретролатерально, сверху. Сокращения: С кондуктор; $\mathrm{CO}$ - копулятивное отверстие; $\mathrm{CPr}$ — вырост цимбиума; DL — верхняя доля ретролатерального отростка голени; Е эмболюс; Et — зубчик эмболюса; MP — медиальная пластинка; Tt - тегулярный зубчик; VL — нижняя доля ретролатерального отростка голени. 
in the genitalia // Zoological Journal of the Linnean Society. Vol.162. P.271-350

Lessert R. de 1946. Araignées du Congo Belge // Revue Suisse de Zoologie. T.58. P.204-225.

Raven R.J. 2015. A revision of ant-mimicking spiders of the family Corinnidae (Araneae) in the Western Pacific // Zootaxa. Vol. 3958. P.1-258.

Saaristo M.I. 2002. New species and interesting new records of spiders from Seychelles (Arachnida, Araneaea [sic]) // Phelsuma. Vol.10. Suppl.A. P.1-31.

Saaristo M.I. 2010. Araneae // Gerlach J., Marusik Y.M. (eds.) Arachnida and Myriapoda of the Seychelles islands. Manchester: Siri Scientific Press. P.8-306.

Shorthouse D.P. 2010. SimpleMappr, an online tool to produce publication-quality point maps, online at http://www. simplemappr.net, accessed 11.9.2019.
Simon E. 1886. Etudes arachnologiques. 18e Mémoire. XXVI. Matériaux pour servir à la faune des Arachnides du Sénégal. (Suivi d'une appendice intitulé: Descriptions de plusieurs espèces africaines nouvelles) // Annales de la Société Entomologique de France. Ser.6. T.5. P.345-396.

Simon E. 1898. Histoire naturelle des araignées. Paris: Roret. T.2. P.193-380.

Simon E. 1910. Arachnides recueillis par L. Fea sur la côte occidentale d'Afrique. 2e partie // Annali del Museo Civico di Storia Naturale di Genova. Vol.44. P.335-449.

Thorell T. 1878. Studi sui ragni Malesi e Papuani. II. Ragni di Amboina raccolti Prof. O. Beccari // Annali del Museo Civico di Storia Naturale di Genova. Vol.13. P.1-317.

WSC. 2019. World Spider Catalog. Version 20.5. Natural History Museum Bern, online at http://wsc.nmbe.ch, accessed on 11.9.2019.

Responsible editor Yu.M. Marusik 